\title{
Actinomadura namibiensis sp. nov.
}

\author{
Joachim Wink, ${ }^{1}$ Reiner M. Kroppenstedt, ${ }^{2}$ Gerhard Seibert ${ }^{1}$ and \\ Erko Stackebrandt ${ }^{2}$
}

Correspondence

Joachim Wink

Joachim.Wink@aventis.com

\author{
${ }^{1}$ Aventis Pharma Deutschland, Drug Innovation and Approval, Natural Products, 65926 \\ Frankfurt, Germany \\ ${ }^{2} \mathrm{DSMZ}$ - Deutsche Sammlung von Mikroorganismen und Zellkulturen, Mascheroder Weg 1b, \\ 38124 Braunschweig, Germany
}

\begin{abstract}
Strain HAG $010767^{\top}$ was isolated from desert soil from Namibia during a screening programme. On the basis of analysis of $16 \mathrm{~S}$ rDNA, the principal amino acid of the peptidoglycan, cell-wall sugars, fatty acids and polar lipids, it was possible to identify this strain as a member of the genus Actinomadura. Although DNA-DNA reassociation experiments revealed $72 \%$ DNA similarity between strain HAG $010767^{\top}$ and Actinomadura kijaniata DSM $43764^{\top}$, significant differences in the colour of the mycelium and physiological properties indicate that strain HAG $010767^{\top}$

represents a novel species of this genus, for which the name Actinomadura namibiensis sp. nov. is proposed. The type strain is strain HAG $010767^{\top}\left(=\mathrm{DSM} 44197^{\top}=\mathrm{NRRL} \mathrm{B}^{-24153^{\top}}\right.$ ).
\end{abstract}

Strain HAG $010767^{\mathrm{T}}$ was isolated from the Namib Desert, Namibia, in 1988, using Actinomycete isolation agar. This salmon-pink strain produced aerial mycelium with spiral spore chains. The strain was compared with the type strains of all validly named Actinomadura species. Morphological and physiological characteristics were observed by using agar cultures of the various media described by Shirling \& Gottlieb (1966), e.g. yeast extract/ malt extract agar (ISP medium 2), oatmeal agar (ISP 3), inorganic salts/starch agar (ISP 4), glycerol/asparagine agar (ISP 5), peptone/yeast extract/iron agar (ISP 6) and tyrosine agar (ISP 7), incubated for 10 days at $28^{\circ} \mathrm{C}$. For scanning electron microscopy, the strain was grown on ISP 4 agar. Microscopy was done as described by Grabley et al. (1992).

Vegetative mycelium developed well on all ISP media tested. Aerial mycelium was formed only on media ISP 4, ISP 5 and ISP 7. No soluble pigment was produced on any of the ISP media tested. After 7-10 days on ISP 4, ISP 5 and ISP 7, the formation of spore chains could be observed. These spores exhibited a smooth surface, and the chains formed spirals that could be observed in both light and scanning electron micrographs (Fig. 1).

The vegetative mycelium was salmon pink [according to the RAL colour code (Deutsches Institut für Gütesicherung und

Published online ahead of print on 9 September 2002 as DOI 10.1099/ijs.0.02286-0.

The EMBL accession numbers for the $16 \mathrm{~S}$ rDNA sequences of A. namibiensis sp. nov. DSM 44197 ${ }^{\top}$ A. echinospora DSM 43163', A. hibisca DSM $44148^{\top}, A$. fulvescens DSM 43923 ${ }^{\top}$, A. atramentaria DSM $43919^{\top}$, A. citrea DSM $43461^{\top}, A$. formosensis DSM $43997^{\top}$ and $A$. viridis DSM $20745^{\top}$ are respectively AJ420134-AJ420141.
Kennzeichnung e.V.-Reichsausschuß für Lieferbedingungen)] on all the ISP media used except medium ISP 6 . The smooth spores in the aerial mycelium are in characteristic long chains that are arranged in spirals (Fig. 1), in contrast with other Actinomadura species such as Actinomadura kijaniata, which have straight spore chains (Fig. 2).

Carbohydrate utilization was investigated on ISP 9 medium (Shirling \& Gottlieb, 1966) by using a microtitre plate technique with 12 -well plates. Sodium chloride tolerance was tested on microtitre plates (6-well) using a technique based on the method of Kutzner (1986). Enzymic activities were determined by using API 20E and API ZYM test strips (bioMérieux) (Humble et al., 1977; Kilian, 1978; Smith et al., 1972). Tests were done with type strains of all validly described Actinomadura species. The carbohydrateutilization pattern and the enzymic activity pattern of strain HAG $010767^{\mathrm{T}}$ were unique among the test strains. Table 1 displays these results in comparison with the phylogenetically neighbouring type strains and the type strain of the type species of Actinomadura, Actinomadura madurae DSM $43067^{\mathrm{T}}$.

Antimicrobial testing (Williams et al., 1983) indicated that none of the test strains, grown either on Mueller-Hinton agar or on Czapek-Dox agar, was affected by isolate HAG $010767^{\mathrm{T}}$.

Analyses of whole-cell diaminopimelic acid isomers and sugars were done using the method of Hasegawa et al. (1983). Phospholipids and menaquinones were analysed using the method of Kutzner et al. (1986). Fatty acid patterns were determined as described previously (Aretz et al., 2000). DL-Diaminopimelic acid is the diagnostic amino acid of the peptidoglycan; the cell wall sugars are 

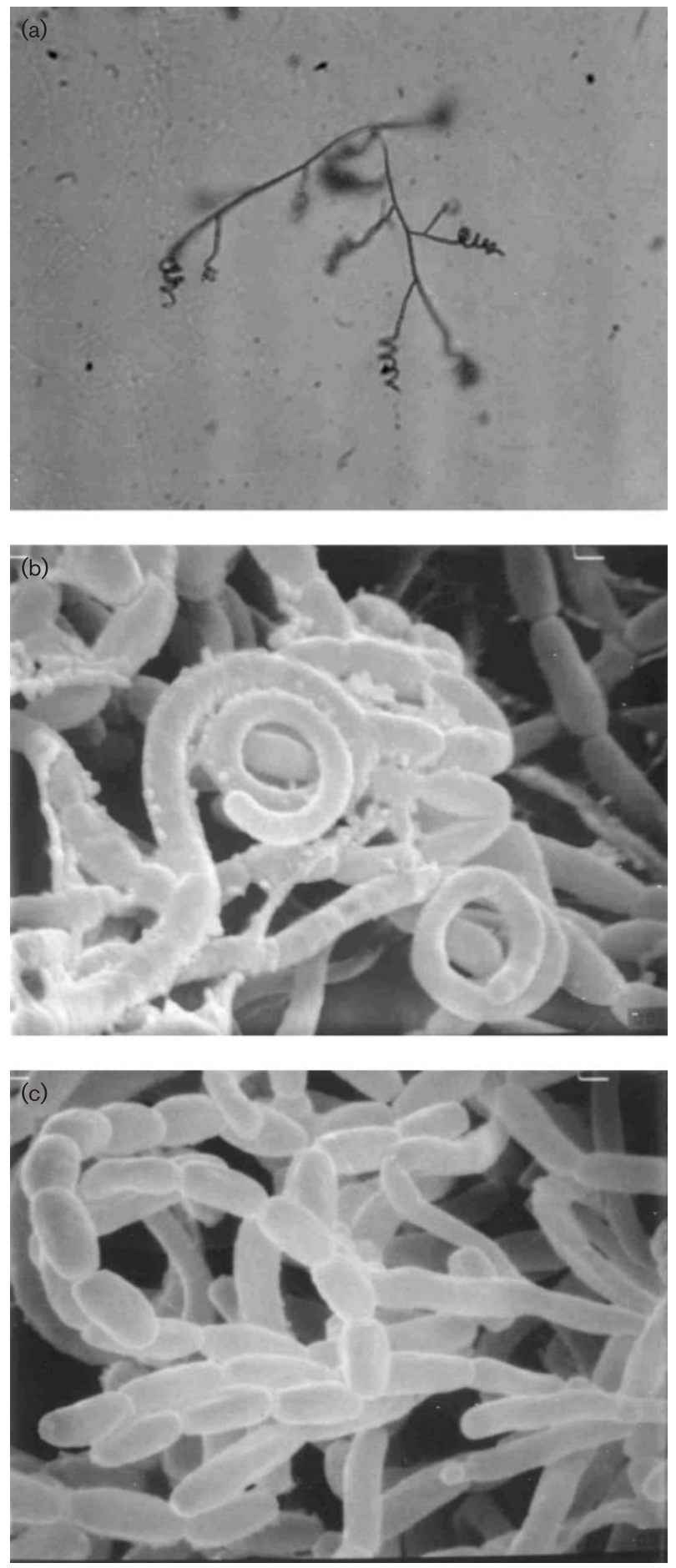

Fig. 1. Spore-chain formation in Actinomadura namibiensis sp. nov. HAG $010767^{\top}$ grown on ISP 4 for 10 days at $28^{\circ} \mathrm{C}$, viewed using light microscopy (a) and scanning electron microscopy (b, c). Original magnification: $\times 620$ (a) and $\times 10000$ (b, c).

galactose, glucose, ribose and madurose (chemotype III according to Lechevalier \& Lechevalier, 1970). Polar lipids are of type IV, according to the phospholipid classification
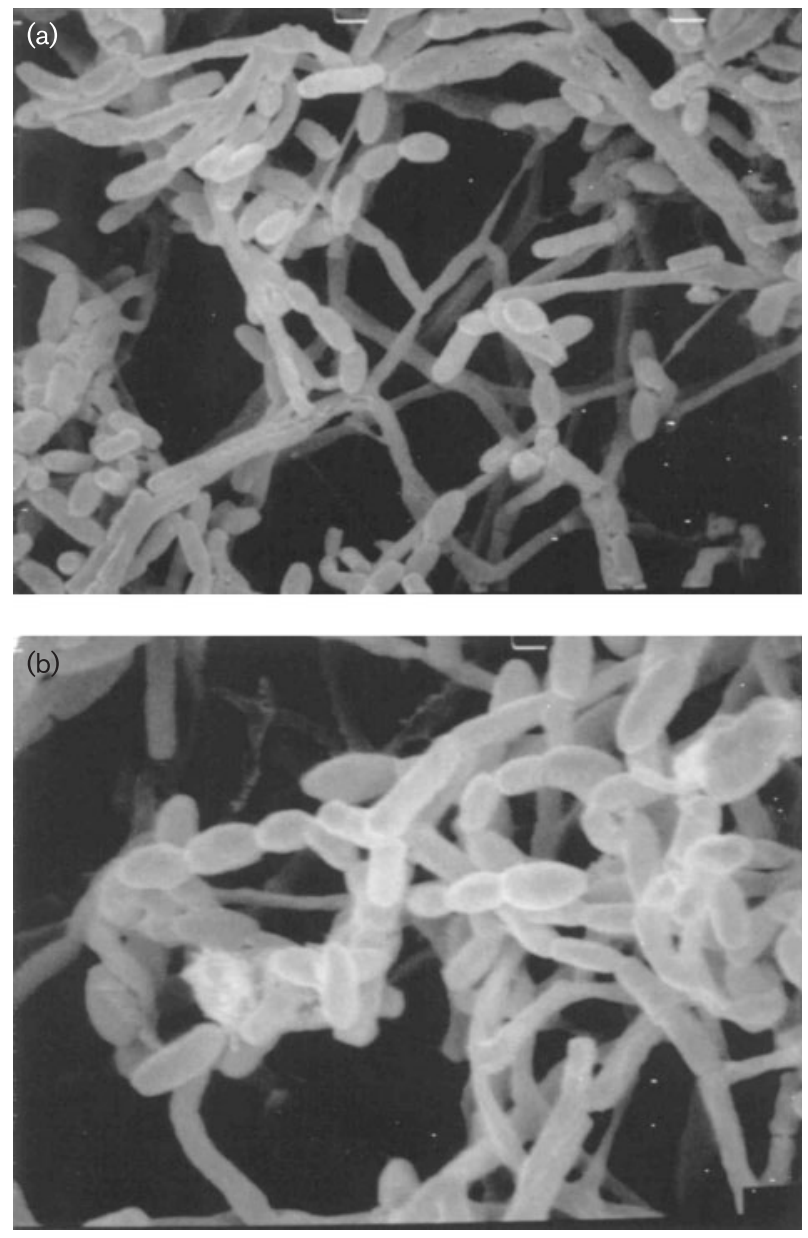

Fig. 2. Spore-chain formation in Actinomadura kijaniata $\mathrm{FH}$ 2339 grown on ISP 4 for 10 days at $28^{\circ} \mathrm{C}$, viewed using scanning electron microscopy. Original magnification: $\times 5000$ (a) and $\times 7500$ (b).

of Lechevalier et al. (1977), and include diphosphatidylglycerol, phosphatidylinositol, phosphatidylglycerol and phosphatidylinositol mannoside. The principal menaquinones are MK-9 $\left(\mathrm{H}_{4}\right)$, MK-9 $\left(\mathrm{H}_{6}\right)$ and MK-9 $\left(\mathrm{H}_{8}\right)$ (quinone type 4a according to Kroppenstedt \& Goodfellow, 1991). The fatty acid methyl esters mainly comprised branched saturated and unsaturated fatty acids and 10-methyl $\mathrm{C}_{18: 0}$ (tuberculostearic acid) (type 3a of Kroppenstedt \& Goodfellow, 1991). Mycolic acids could not be detected.

Analysis of the almost complete $16 \mathrm{~S}$ rDNA sequence (Rainey et al., 1996) of strain HAG $010767^{\mathrm{T}}$ in comparison with the sequences of type strains of all 27 validly described Actinomadura species revealed a high degree of relatedness (96-99.6\% similarity). The highest value $(99.6 \%)$ was found to A. kijaniata DSM $43764^{\mathrm{T}}$. A relationship dendrogram, based on neighbour-joining analysis (Felsenstein, 1993), is depicted in Fig. 3. Discrimination at a higher taxonomic level by DNA-DNA hybridization (Escara \& Hutton, 1980; Huß et al., 1983; Jahnke, 1992) revealed that 
Table 1. Utilization of carbohydrates and enzymic reactions

Strains are listed as: 1, HAG $010767^{\mathrm{T}}$; 2, Actinomadura kijaniata ATCC $31588^{\mathrm{T}}$; 3, Actinomadura atramentaria DSM 43919 ${ }^{\mathrm{T}}$; 4 , Actinomadura fibrosa ATCC $49459^{\mathrm{T}} ; 5$, Actinomadura fulvescens DSM $43923^{\mathrm{T}}$; 6, Actinomadura madurae CBS $3315^{\mathrm{T}}$; 7, Actinomadura hibisca IFO $15585^{\mathrm{T}}$; 8, Actinomadura nitritigenes DSM $44137^{\mathrm{T}}$. For utilization tests, growth is scored as: + , like positive control (basal medium with glucose); $(+)$, better than negative control but not like positive control; - , not better than negative control (basal medium with water). All strains are positive for acid phosphatase, leucine arylamidase, naphthol-AS-BI-phosphohydrolase and $\beta$-glucosidase and negative for $\beta$-glucuronidase.

\begin{tabular}{|c|c|c|c|c|c|c|c|c|}
\hline Characteristic & 1 & 2 & 3 & 4 & 5 & 6 & 7 & 8 \\
\hline \multicolumn{9}{|l|}{ Utilization of: } \\
\hline Glucose & + & - & + & + & + & + & + & - \\
\hline Arabinose & + & - & - & + & - & + & + & - \\
\hline Sucrose & + & - & - & + & - & + & + & + \\
\hline Xylose & $(+)$ & - & - & - & - & - & + & - \\
\hline Inositol & $(+)$ & - & - & + & - & + & + & + \\
\hline Mannitol & $(+)$ & - & - & - & - & - & + & + \\
\hline Fructose & - & - & - & + & - & + & + & + \\
\hline Rhamnose & + & - & + & + & - & $(+)$ & + & - \\
\hline Raffinose & - & - & - & + & - & - & + & + \\
\hline \multicolumn{9}{|l|}{ API ZYM tests: } \\
\hline Alkaline phosphatase & + & + & - & + & + & + & + & + \\
\hline Esterase $\left(\mathrm{C}_{4}\right)$ & - & + & + & + & + & - & + & - \\
\hline Esterase $\left(\mathrm{C}_{8}\right)$ & - & + & + & + & + & + & + & + \\
\hline Lipase $\left(\mathrm{C}_{14}\right)$ & - & + & - & - & - & - & - & - \\
\hline Valine arylamidase & + & + & - & + & + & - & + & + \\
\hline Cystine arylamidase & + & + & - & - & + & - & + & + \\
\hline Trypsin & + & - & - & + & + & - & + & + \\
\hline Chymotrypsin & + & + & - & + & + & + & + & - \\
\hline$\alpha$-Galactosidase & + & - & - & - & - & - & - & - \\
\hline$\beta$-Galactosidase & + & + & - & - & + & - & $(+)$ & - \\
\hline$\alpha$-Glucosidase & + & + & - & + & + & - & + & + \\
\hline$N$-Acetyl- $\beta$-glucosamidase & + & + & - & + & + & - & + & + \\
\hline$\alpha$-Mannosidase & + & - & - & - & - & - & - & + \\
\hline$\alpha$-Fucosidase & - & - & - & - & - & - & $(+)$ & - \\
\hline \multicolumn{9}{|l|}{ API20E tests: } \\
\hline Arginine dihydrolase & - & + & - & - & + & - & + & + \\
\hline Lysine decarboxylase & - & + & - & - & + & - & + & - \\
\hline Ornithine decarboxylase & - & + & - & - & + & - & + & - \\
\hline Citrate utilization & - & + & - & - & + & - & + & + \\
\hline Urease & - & + & + & + & + & - & - & - \\
\hline Acetoin production & - & - & + & + & + & - & - & - \\
\hline Gelatinase & - & - & + & + & + & + & + & + \\
\hline
\end{tabular}

these two strains constitute two closely related genomic taxa ( $72 \%$ similarity, mean of duplicates).

On the basis of the presence of genus-specific chemotaxonomic properties, and supported by its phylogenetic position, strain HAG $010767^{\mathrm{T}}$ is a member of the genus Actinomadura. Though phylogenetically highly related to A. kijaniata, the presence of diagnostic carbon-utilization and enzyme patterns (using APY ZYM) and the colour of the

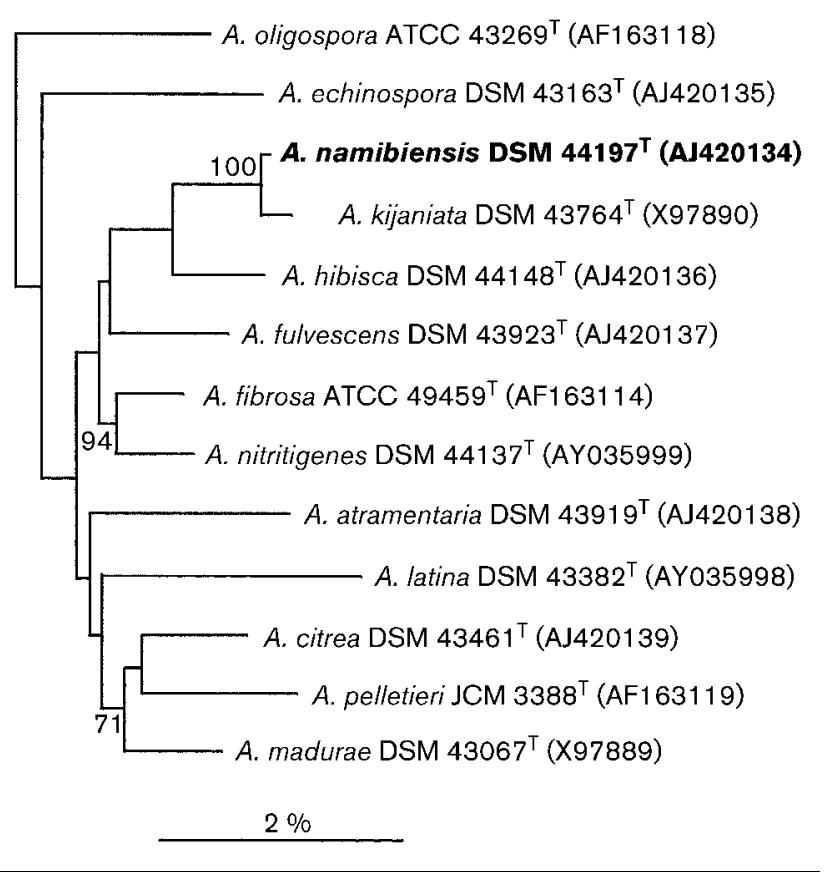

Fig. 3. $16 \mathrm{~S}$ rDNA dendrogram showing the positions of strain HAG $010767^{\top}$ and type strains of phylogenetically closely related Actinomadura species. Scale bar, 2 inferred nucleotide substitutions per 100 nucleotides.

substrate mycelium (HAG $010767^{\mathrm{T}}$, salmon; A. kijaniata, green) indicate that strain HAG $010767^{\mathrm{T}}$ represents a taxon worthy of species status. We therefore propose the name Actinomadura namibiensis sp. nov., with strain HAG $010767^{\mathrm{T}}$ as the type strain.

\section{Description of Actinomadura namibiensis sp. nov.}

Actinomadura namibiensis (na.mi.bi.en'sis. N.L. gen. n. namibiensis of Namibia, where the type strain was isolated).

Gram-positive. White aerial mycelium develops only on ISP 4, ISP 5 and ISP 7 media. The substrate mycelium is salmon pink on ISP 2, ISP 3, ISP 4, ISP 5 and ISP 7 media and is colourless on ISP 6 . After about 10 days, spiral spore chains, each composed of about 20 spores, are observed in the aerial mycelium. DL-Diaminopimelic acid is the diagnostic amino acid of the peptidoglycan. Cell hydrolysates contain galactose, glucose, ribose and madurose, whereas arabinose and xylose are absent. Phospholipids include diphosphatidylglycerol, phosphatidylglycerol, phosphatidylinositol mannoside and phosphatidylinositol. The principal menaquinones are MK-9 $\left(\mathrm{H}_{4}\right), \mathrm{MK}-9\left(\mathrm{H}_{6}\right)$ and $\mathrm{MK}-9\left(\mathrm{H}_{8}\right)$. The fatty acid methyl esters mainly comprise iso $\mathrm{C}_{14: 0}$ and 10-methyl $\mathrm{C}_{18: 0}$ (tuberculostearic acid); iso $\mathrm{C}_{17: 0}, 10$ methyl $\mathrm{C}_{17: 0}$ and 2-OH $\mathrm{C}_{15: 0}$ occur in smaller amounts. Physiological reactions are indicated in Table 1. Has no antibacterial effect on Micrococcus luteus, Streptomyces murinus, Bacillus subtilis, Staphylococcus aureus, Escherichia 
coli, Pseudomonas aeruginosa, Saccharomyces cerevisiae, Aspergillus niger or Candida albicans. Phylogenetically related to Actinomadura kijaniata.

The type strain, strain HAG $010767^{\mathrm{T}}\left(=\mathrm{DSM} 44197^{\mathrm{T}}\right.$ $=$ NRRL B-24153 ${ }^{\mathrm{T}}$ ), was isolated from soil from the Namib Desert, Namibia.

\section{References}

Aretz, W., Meiwes, J., Seibert, G., Vobis, G. \& Wink, J. (2000). Friulimicins: novel lipopeptide antibiotics with peptidoglycan synthesis inhibiting activity from Actinoplanes friuliensis sp. nov. I. Taxonomic studies of the producing microorganism and fermentation. J Antibiot 53, 807-815.

Escara, J. F. \& Hutton, J. R. (1980). Thermal stability and renaturation of DNA in dimethyl sulfoxide solutions: acceleration of the renaturation rate. Biopolymers 19, 1315-1327.

Felsenstein, J. (1993). PHYLIP - Phylogeny inference package, version 3.5.1. Distributed by the author. Department of Genetics, University of Washington, Seattle, USA.

Grabley, S., Granzer, E., Hütter, K. \& 7 other authors (1992). Secondary metabolites by chemical screening. 8. Decarestrictines, a new family of inhibitors of cholesterol biosynthesis from Penicillium. I. Strain description, fermentation, isolation and properties. J Antibiot 45, 56-65.

Hasegawa, T., Takizawa, M. \& Tanida, S. (1983). A rapid analysis for chemical grouping of aerobic Actinomycetes. J Gen Appl Microbiol 29, 319-322.

Humble, M. W., King, A. \& Phillips, I. (1977). API ZYM: a simple rapid system for the detection of bacterial enzymes. J Clin Pathol 30, 275-277.

Huß, V. A. R., Festl, H. \& Schleifer, K. H. (1983). Studies on the spectrophotometric determination of DNA hybridization from renaturation rates. Syst Appl Microbiol 4, 184-192.
Jahnke, K.-D. (1992). BASIC computer program for evaluation of spectroscopic DNA renaturation data from Gilford System 2600 spectrophotometer on a PC/XT/AT type personal computer. J Microbiol Methods 15, 61-73.

Kilian, M. (1978). Rapid identification of Actinomycetaceae and related bacteria. J Clin Microbiol 8, 127-133.

Kroppenstedt, R. M. \& Goodfellow, G. (1991). The family Thermomonosporaceae. In The Prokaryotes, 2nd edn, pp. 10851114. Edited by A. Balows, H. G. Trüper, M. Dworkin, W. Harder \& K. H. Schleifer. New York: Springer.

Kutzner, H. J., Kroppenstedt, R. M. \& Korn-Wendisch, F. (1986). Methoden zur Untersuchung von Streptomyceten und einigen anderen Actinomyceten, 4th edn. Report of the Institute for Microbiology, Technical University, Darmstadt and German Culture Collection (DSMZ), Braunschweig. Braunschweig: DSMZ.

Lechevalier, M. P. \& Lechevalier, H. A. (1970). Composition of whole cell hydrolysates as a criterion in the classification of aerobic actinomycetes. In The Actinomycetales, pp. 311-316. Edited by H. Prauser. Jena: Gustav Fischer.

Lechevalier, M. P., de Bièvre, C. \& Lechevalier, H. A. (1977). Chemotaxonomy of aerobic actinomycetes: phospholipid composition. Biochem Ecol Syst 5, 249-260.

Rainey, F. A., Ward-Rainey, N., Kroppenstedt, R. M. \& Stackebrandt, E. (1996). The genus Nocardiopsis represents a phylogenetically coherent taxon and a distinct actinomycete lineage: proposal of Nocardiopsaceae fam. nov. Int J Syst Bacteriol 46, 1088-1092.

Shirling, E. B. \& Gottlieb, D. (1966). Methods for characterization of Streptomyces species. Int J Syst Bacteriol 16, 313-340.

Smith, P. B., Thomfohrde, K. M., Rhoden, D. L. \& Balows, A. (1972). API system: a multitube micromethod for identification of Enterobacteriaceae. Appl Microbiol 24, 449-452.

Williams, S. T., Goodfellow, M., Alderson, G., Wellington, E. M. H., Sneath, P. H. A. \& Sackin, M. J. (1983). Numerical classification of Streptomyces and related genera. J Gen Microbiol 129, 1743-1813. 